\title{
Organ Measurements Sequence Number
}

National Cancer Institute

\section{Source}

National Cancer Institute. Organ Measurements Sequence Number. NCI Thesaurus. Code C119892.

An identifier that describes the relative position of organ measurement data within a series. 